\title{
Dinamika Pelayanan Lembaga Sosial: Resistensi Pekerja Sosial di Yayasan Sayap Ibu Cabang Yogyakarta
}

\author{
Rohimi \\ Pascasarjana UIN Sunan Kalijaga Yogyakarta \\ Email: dinobastian11@gmail.com \\ Octri Amelia Suryani \\ Pascasarjana UIN Sunan Kalijaga Yogyakarta \\ Email: octriamelia@gmail.com
}

Naskah diterima: 15 Januari 2020| Naskah disetujui: 05 Maret 2020

\begin{abstract}
Social work is a profession that has been born since a few centuries ago, even the social work profession has been recognized globally is International Federation of Social Work (IFSW). IFSW is a form of recognition of the existence of social work as a profession. However, talking about social work, will never be separated with its substance related to how to provide services to individuals, groups, and society. Every action must have challenges and obstacles, as well as the social work profession. This paper specifically addresses the challenges of managing social work services at the Sayap Ibu Yogyakarta Foundation. This study uses an empirical or qualitative approach, with data collection methods of observation, interviews, and documentation. The results and discussion obtained in this study related to the pattern of management challenges occur from several indications namely lack of funding, resignation of an employee, lack of social workers and caregivers in the institution, and when talking about management challenges will certainly trigger various impacts such as lack of effectiveness in provide services to clients, lack of resources for clients, especially about basic needs, weak service processes and make services inefficient. Whereas resistance from employees or head of institutions in dealing with management problems in the institution that is acting dynamically in seeking funding such as submitting proposals to the company, conducting evaluations that implicate all employees of institutions, both social workers to child caregivers and looking for social workers such as looking for employee employees, especially those who are ready to work physically and mentally taking care of clients.
\end{abstract}

Keywords: Effectiveness, social service, patterns, impacts, resistance 


\begin{abstract}
Abstrak
Pekerjaan sosial merupakan profesi yang telah lahir sejak dari beberapa abad yang lalu, bahkan profesi pekerjaan sosial sudah diakui secara menggelobal yakni Internasional Federation of Social Work (IFSW). Dimana IFSW menjadi bentuk pengakuan terhadap eksistensi pekerjaan sosial sebagai sebuah profesi. Akan tetapi berbicara tentang pekerjaan sosial, tidak akan pernah lepas dengan substansinya terkait dengan bagaimana memberikan pelayanan terhadap individu, kelompok, maupun masyarakat. Namun, dimana kita ketahui, bahwa dalam setiap tindakan pasti memiliki tantangan dan kendala, begitu pula dengan profesi pekerjaan sosial. Akan tetapi didalam tulisan ini membahas secara spesifik terkait dengan tantangan manajemen pelayanan pekerjaan sosial di Yayasan Sayap Ibu Cabang Yogyakarta. Penelitian ini menggunakan pendekatan empiris atau kualitatif, dengan metode pengumpulan data observasi, wawancara, dan dokumentasi. Hasil dan pembahasan yang diperoleh dalam penelitian ini terkait dengan pola tantangan manajemen terjadi dari beberapa indikasi yakni kurangnya pendanaan, pemunduran diri seorang pegawai, kurangnya pekerja sosial dan pengasuh di dalam panti, dan ketika berbicara tentang tantangan manajemen tentu akan memicu berbagai dampak seperti kurangnya keefektifan dalam memberikan layanan kepada klien, kurangnya sumber untuk klien terutama tentang kebutuhan dasar, lemahnya proses pelayanan dan menjadikan pelayanan tidak efisien. Sedangkan resistensi dari pegawai atau kepala panti dalam menghadapi problem manajemen di lembaga yakni bertindak dinamis dalam mencari pendanaan seperti mengajukan proposal ke perusahaan, melakukan evaluasi yang mengimplikasi semua pegawai lembaga baik itu pekerja sosial sampai pengasuh anak dan mencari sousi seperti mencari penggati pegawai terutama yang siap bekerja lahir batin mengurus klien.
\end{abstract}

\title{
Kata Kunci: Efektifitas, pelayanan sosial, pola, dampak, resistensi
}

\section{Pendahuluan}

Pekerjaan sosial merupakan profesi yang terlahir sejak beberapa abad yang lalu, pekerjaan sosial yang terlahir sebagai sebuah profesi yang dilandasi dengan jiwa kemanusiaan dalam melihat permasalahan terhadap orang lain yang akan diberiakn pelayanan dan intervensi dalam mengatasi masalah yang dihadapinya. Pekerjaan sosial sebagai sebuah profesi juga tidak lepas dari beberapa indikasi yang melatarbelakanginya seperti pengetahuan, keterampilan dan nilai-nilai tertentu yang melekat pada profesi pekerjaan sosial (Suharto, 2009: 24-25).

Maka, ketika mendengar profesi sebagai pekerja sosial, tidak lepas dari bagaimana memberikan bantuan terhadap orang lain atau dengan slogan khusus yakni membantu orang untuk mampu membantu dirinya sendiri (helping people to helping themselves). Sebagai salah satu fungsi dari pekerjaan sosial untuk mengembalikan keberfungsian sosial suatu individu, keluarga, kelompok maupun masyarakat. Sehingga 94 
kata intervensi yang selalu melekat pada profesi pekerjaan sosial, tidak lepas secara substansi tentang bagaimana bekerja untuk membantu dalam mengupayakan keberfungsian sosial dari kliennya (Huda, 2009: 25-26).

Oleh karena itu, pekerjaan sosial ini tidak akan bisa dipisahkan dengan konsep kasih sayang atau rasa humanitarianisme terhadap orang lain sebagaimana telah disinggung di atas. Pekerjaan sosial juga merupakan profesi yang tidak jauh dari rasa menjujung tinggi keadilan bersama atau rasa kasih sayang yang biasa disebut didalam konsep pekerjaan sosial yakni filantropi (kedermawanan/kesukarelaan). Sehingga dari rasa semangat untuk melayana dan menolong orang lain itulah yang menjadikan benihbenih jiwa filantropi ini menjadikan pekerja sosial sebagai profesi yang bersifat memberi dan menolong (Huda, 2009: 42). Mengingat kelahiran profesi pekerjaan sosial menjadi strategi dari kesejahteraan sosial, dimana tidak akan lepas dari bagaimana melakukan sesuatu untuk berupaya dalam membantu permasalahan yang dihadapi oleh individu sampai masyarakat. (Huda, 2009: 45).

Sehingga sudah banyak representasi terkait teori-teori tentang pekerjaan sosial, bahkan dari organisasi global pekerjaan sosial juga banyak menerapkan pendapat dan teori-teori mengenai pekerjaan sosial. Misalnya Internasional Federation of Social Work (IFSW) telah mengemukakan berbagai macam definisi bahwa pekerjaan sosial merupakan profesi yang bertujuan untuk perubahan sosial, memecahkan masalah yang selalu berkaitan dengan relasi kemanusiaan dan memberdayakan kaum-kaum yang lemah atau belum berdaya atau disadvantages group. (Najib, 2018: 5).

Namun, profesi ini tidak lepas dari satu tujuannya yakni memecahkan masalah yang dihadapi oleh individu. Menurut Zastrow yang dikutip oleh Dwi mendefinisikan tujuan pekerjaan sosial tidak lain untuk meningkatkan fungsi sosial suatu individu, memotivasi dan selalu menggerakan niat kemanusiaanya guna memberikan pelayanan yang maksimal untuk seorang klien.(Sukonco, 2006: 25) Sehingga pekerjaan sosial juga merupakan profesi yang terorganisasi dan melembaga, dimana didalam suatu lembaga atau organisasi sosial tersebut menjadi tempat merehabilitasi klien-kliennya, karena ketika berbicara tentang pekerjaan sosial juga merupakan profesi yang tentu memiliki metode atau kinerja dalam memberikan pertolongan yakni mikro (individu), messo (keluarga), dan makro (masyarakat) (Najib, 2018: 19-20). 
Dari metode pekerjaan sosial itu merupakan bentuk konseling yang harus melayani berbagai macam permasalahan yang harus diberikan secara kuratif atau pertolongan bagi kliennya. Dimana konseling merupakan bentuk arahan yang harus diberikan layanan dan bantuan untuk memecahkan suatu permasalahan (Dewi, 2016: 308). Menurut Santoso, bahwasanya organisasi layanan sosial bertujuan untuk memberikan bantuan kepada masyarakat yang mengalami suatu permasalahan guna memberikan tindakan untuk membantu memecahkan masalah. Dengan demikian, dalam setiap layanan organisasi sangat membutuhkan manajemen maupun administrasi yang efektif, guna memberikan layanan yang efektif dan sesuai dengan struktur organisasi tersebut. Pusat layanan sosial juga merupakan salah satu bagian dari organisasi layanan yang memiliki orientasi atau tugas yang bertujuan untuk kesejahtraan sosial. (ST. Raharjo, 2002: 2).

Namun, didalam kontak internal tentu sangat membutuhkan agen-agen yang siap bekerja dengan maksimal kepada klien yang harus diberikan bantuan atau pertolongan untuk membantu memecahkan masalah yang mereka hadapi, dan didalam suatu proses layanan yang akan diberikan, suatu organisasi layanan sosial membutuhkan sumber daya yang harus mampu bekerja bersama dengan semua anggota didalam suatu organisasi, sehingga mampu memanfaatkan sumber-sumber yang ada dalam menyelenggarakan pelayanan sosial. (ST. Raharjo, 2002: 3).

Didalam ogranisasi sosial juga merupakan organisasi yang terorganisir dalam mengupayakan kinerja yang efektif, dimana keefektifan tersebut membantu proses pelayanan yang sangat stabil bagi organisasi itu sendiri. Akan tetapi, dalam setiap pelayanan kerap kali disandingi dengan berbagai proses tantangan dalam memberikan layanan, dimana didalam oragnisasi sosial di Yayasan Sayap Ibu Cabang Yogyakarta, juga tak selamanya memliki layanan yang stabil dan terus berjalan efektif. Akan tetapi banyak kendala yang mempengaruhi proses layanan yang tidak maksimal dalam memberikan layanan terhadap klien maupun terhadap agen-agen di dalam yayasan tersebut.

Tantangan memang tidak bisa kkita pungkiri selalu hadir dalam situasi apapun, apalagi dalam soal pelayanan atau kelemabagaan. Dari hasil observasi peneliti disini, bahwasannya berbicara tentang tantangan manajemen di lembaga Yayasan Sayap Ibu Cabang Yogyakarta itu tidak lepas tantangan itu muncul secara fundamental yakni 
seperti terkait dengan pendanaan dari suatu lembaga tersebut. Kemudian tidak hanya dengan fenomena pendanaan atau financial, akan tetapi tetangan kerap kali muncul di setiap administrasi manajemen kelembagaan. Misalnya di Yayasan Sayap Ibu Cabang Yogyakarta itu tidak lepas dari pemunduran diri seorang pegawai dari kelembagaan (resign), dan itu juga menjadi tantangan dalam manajamen di dalam lembaga Yayasan Sayap Ibu Cabang Yogyakarta. Mengingat tentang berbagai indikasi tantangan tersebut, tidak lepas juga berdampak dalam mengelola suatu kelembagaan untuk mencapai tujuan, dimana tantangan mmemang menjadi sebuah acuan menghadirkan dampak negatif dalam kinerja kelemabagaan ataupun lebih ironis lagi menyebabkan ketidak efektifan dalam memberikan pelayanan.

Jika kita berbicara mengenai pelayanan, Yayasan Sayap Ibu merupakan kelembagaan atau organisasi sosial yang terfokus pada rehabilitasi anak terlantar mulai dari usia 0-sampai usia lansia. Akan tetapi berbicara tentang eksistensi Yayasan Sayap Ibu Cabang Yogyakarta, itu merupakan organisasi sosial non-profit sehingga eksistensi organisasi ini, memang murni menjadi organisasi sosial yang berdiri sendiri dan mandiri. Namun, dengan kemandiriannya, Yayasan Sayap Ibu Cabang Yogyakarta juga mampu mengelola sampai tiga LKSA atau tiga panti, yakni panti anak terlantar dari usia 0-6 tahun, panti anak terlantar usia remaja dan panti bagi lansia.

Didalam tulisan ini, peneliti lebih memfokuskan pada panti pertama yakni dengan rehabilitasi klien anak terlantar usia 0-6 tahun. Mengingat beberapa uraian problematika yang terjadi di Yayasan Sayap Ibu Cabang Yogyakarta, tidak lepas dari awal peneliti memulai dan menggali rujukan dalam penelitian ini terkait dengan isu-isu yang menghambat pelayanan dan keefektifan organisasi serta dampak adanya tantangan-tantangan dalam suatu manajemen didalam kelembagaan atau organisasi tersebut.

\section{Metode Penelitian}

Penelitian bertujuan untuk menemukan jawaban atau kebenaran atas suatu fakta sosial yang terjadi. Didalam penelitian ini, peneliti menggunakan penelitian lapangan atau kualitatif dengan pendekatan empiris (Empirical approach). Penelitian ini disusun bertujuan dalam menganalisis permasalahan terhadap tantangan manajemen di lembaga Yayasan Sayap Ibu Cabang Yogyakarta, dimana tantangan manajemen ini juga memicu 
atau berdampak dalam menghambat keefektifan dalam memberikan pelayanan yang kondusif dan efisien terhadap klien. Proses pengambilan data yang digunakan didalam penelitian ini menggunakan beberapa metode yakni wawancara, observasi dan dokumentasi, dan responden yang diimplikasi didalam penelitian ini guna mendapatkan jawaban atau kebenaran atas permasalahan di lembaga sosial terkait dengan tantangan manajemen yakni wawancara dengan kepala lembaga, pekerja sosial dan staf administrasi dan pengasuh anak.

\section{Kerangka Teori}

\section{Konsep tentang Administrasi dan Manajemen}

Administrasi merupakan salah satu bentuk pelayanan yang perlu ditingkatkan dengan keefektifan yang maksimal. Administrasi menurut asal katanya yakni "administrate" berarti melayani dan juga membantu. Sehingga secara harfiah manajemen berarti orang yang memberikan tugas layanan dan membantu orang lain dalam bentuk dokumen, sehingga seorang administrator harus mampu memberikan layanan yang benar. Oleh karena itu, dari pola kinerjanya administrasi mengandung pengertian dan makna proses pekerjaan yang berhubungan dengan ketatausahaan dan proses layanan dalam bentuk pemberkasan-pemberkasan. Sehingga administrasi sangat dekat dengan hal-hal yang berkaityan dengan pengelolaan agar menjadi lebih efektif dalam suatu pekerjaan (Usman, 2013: 1-2).

Didalam pembentukan administrasi yang efektif tentu harus ada manajemen yang juga perlu sangat diperhatikan, baik manajemen secara individual maupun manajemen secara kinerja dan tugas-tugas, dimana manajemen merupakan melakukan suatu tindakan, dan manajemen ini di perani oleh seorang manajer berarti manajer merupakan orang yang melayani dengan menangani. Manajemen menurut Parker yang dikutip oleh Husaini, manajemen merupakan tindakan untuk melaksanakan pekerjaan yang efektif, sedangkan menurut Sapre, manajemen merupakan bentuk arahan yang bertujuan untuk membangun sumber daya manusia atau organisasi yang efisien guna mencapai suatu tujuan (Usman, 2013: 5-6).

Dengan demikian, antara manajemen dan administrasi ada kaitan yang sangat koheren, dimana manajemen mampu berperan pada suatu admnistrasi dan menciptakan keefektifan pada suatau hasil dari administrasi tersebut, karena administrasi memiliki 
pengertian berarti ketatausahan atau ketatalaksanaan, sedangkan manajemen merupakan bentuk pengelolaan dari pekerjaan yang berkaitan dengan administrasi. (Farikhah, 2011: $1)$.

Menurut Hikmat yang dikutip oleh Siti Farikhah memaparkan prinsip dari manajemen yakni pertama, prisip efisien dan efektifitas merupakan bentuk tindakan yang dilakukan dengan benar dan mudah. Kedua prinsi pengelolaan merupakan bentuk perencanaan, pengorganisasian, dan usaha untuk mengontrol. Ketiga, prinsip penutamaan tugas merupakan bentuk tanggung jawab atas suatau kinerja secara khusus atau untuk organisasi secara umumnya, dan juga menjadi bentuk tanggung jawab manajer maupun agen-agen pada suatu organisasi atau lembaga. Keempat, prinsip kepemimpinan efektif merupakan bentuk korelasi atau hubungan antara manajer dengan anggota yang harus saling merealisasikan. Sehingga pemimpin pada prinsip ini harus bijaksana dan menjalanka tugas-tugasnya dengan efektif. Kelima, prinsip kerjasama merupakan bentuk komitmen dalam suatu struktur organisasi atau lembaga yang terus mencerminkan keefektifan dalam memberikan tugas dan menjalani kinerja yang ada (Farikhah, 2011: 18-20).

\section{Konsep tentang Pelayanan Sosial}

Berbicara tentang pelayanan sosial tidak lepas dari konsep bagaimana memberikan bantuan, mengurus dan merawat. Dalam Kamus Besar Bahasa Indonesia, pelayanan berarti mengurus atau melayanan, sedangkan pelayan berarti orang yang mengurus. Maka, pelayanan itu tindakan yang terindikasi dalam bentuk melayani, seperti melayani orang tidak berdaya. Pengertian pelayanan menurut Budiono yang di kutip oleh Vici, pelayanan merupakan bentuk atau proses memberikan bantuan kepada orang lain dengan cara ternetu, bisa menggunakan cara interpersonal maupun dengan cara terorganisi (Yulian, 2006).

Sedangkan pelayanan sosial berarti menunjukkan suatu kegiatan yang terotrganisir didalam suatu lemabaga yang memiliki program-program tertentu yang direpresentasikan untuk meningkatkan keberfungsian individu, kelompok maupun masyarakat, terutama berorientasi pada orang-orang yang belumberuntung, seperti orang cacat, anak terlantar dan lansia (Husna, 2009, 24). Sedangkan menurut Brenda Dubois yang di kutip oleh Nazarudin, menyebutkan pelayanan sosial sebagai bentuk 
dukungan dalma meningkatkan keberfungisan individu, memneuhi kebutuhan dasarnya, dan meningkatkan pola kepribadian individu didalam suatu lembaga (Nazarudin, 2001: 201). Berbicara tentang pelayanan sosial, sejatinya berbicara tentang bagaimana perlindungan sosial itu sendiri, dimana perlindungan sosial merupakan bentuk intervensi atau pelayanan dalam membantu orang lain menghadapi permasalahannya. Melihat dari tujuan perlindungan sosial, bahwa perlindungan sosial tidak jauh dari bagaiman merealisasikan suatu pelayanan tersebut misalnya membantu mengurasi risiko yang dihadapi oleh manusia, meningkatkan kemampau kaum rentah bawah atau lemah (disadvantages group.) (Suharto, 2013: 42-43).

Sedangkan Suharto melihat pelayanan itu membagikan menjadi beberapa bagian misalnya pelayanan itu bersifat berada dalam garis terorganisir yang memiliki tujuan yang akurat dan misi yang jelas, menggerakka sumber daya manusia untuk mampu bekerja dengan semandi-mandirinya, membantu memecahkan suatu permasalahn yang dihadapi oleh klien, membantu memberikan akses agar berjalan dengan kehidupa yang lebih mandiri dan melakukakn relasi dengan stakeholders di luar kendalinya atau dengan organisasi-organisasi sosial lainnya (Suharto, 2009: 95).

\section{Konsep tentang Efektifitas Organisasi}

Secara etimologi efektifitas berarti berasal dari kata efektif yang artinya berhasil dan berguna. oleh karena itu, efektifitas merupakan bentuk pencapaian tujuan dari apa yang telah dikerjakan, bahkan efektifitas merupakan bentuk alternatif untuk memnentuan pilihan yang ingin di capai. Menurut Kamarudin yang di kutip oleh Mohamad, menjelaskan tentang efektifitas merupakan pola keadaan dalam menunjukkan keberhasilan mapun bentuk manajamen dalam mencapai tujuan yang telah direncanakan (Mohamad, 2010: 23).

Dapat disimpulkan bahwa pekerjaan dapat dilaksanakan dengan baik sesuai target, bahkan mampu menghasilkan keefektifan dan efisien sesuai dengan yang telah direncanakan. Efektifitas sangat menjadi setiap agen-agen dalam melakukan kinerja agar pekerjaannya mampu mmberikan hasil yang kondusif. Oleh karena itu, kinerja yang menjamin keefektifan harus melakukan pendampingan maupun pekerjaan yang sifatnya mampu mendampngi dan merencanakan pelbagai macam program, kemudian mengikut sertakan semua pihak elemen, misalnya di dalam suatu lembaga untuk 
menjadi pelaku aktif dalam melakukan program maupun kegiatan yang berada dalam lingkup yang terorganisir (Mohamad, 2010: 25).

Menurut mahmudi yang di kutip oleh Bryan, efektivitas merupakan bentuk output atau hasil dari sebuah kegiatan yang dilakukan. Efektifitas juga tanda output, karena semakin besar tanda kontribusi maka semakijn besar keefektifan yang dicapai, misalnya di dalam suatu organisasi, efekgtifitas mencerminkan hasil dari kegiatan dan kinerja yang dilakukan oleh agen-agen didalam suatu organisasi itu sendiri baik dari pemimpian atau kepala lembaga sampai dengan staf-stafnya. Bahkan organisasi bisa dikatakan efektif bila mampu memenuuhi syarakat dalam menjamin keefektifan dari waktu, kecermatan dan gaya pemberian layanan.

Pertama, Efektif terhadap waktu dalam suatu organisasi memberikan pelayanan harus jelas dengan kriteria waktu (time), karena itu juga termasuk dari kriteria dan keberhasilan oragnisasi itu sendiri. Oleh karena itu waktu menjadi faktir dalam menentukan keberhasilannya pelayanan yang dilakukan. Kedua, kecermatan termasuk kedalam keefektifan suatu organisasi misalnya dalam memberikan pelayanan dengan waktu yang singkat atau lama, namun tetap menjamin suatu tanggung jawab yang diberikan dari agen-agen dalam organisasi tersebut. Dan terakhir, gaya agensi dalam memberikan pelayanan merupakan bentuk tolak ukur dari suatu organisasi dalam mencerminkan hasil yang efektif dan efisiensi. Substani dalam gaya pemberian layanan ini mencerminkan pola kinerja dan pelayanan dari karyawan untuk memberikan pelayana terhadap orang lain atau klien-kliennya (Monteiro, 2019, 295-296)

Berbicara tentang organisasi, tentu tidak lepas bagaimana cara memanajamen suatu organisasi itu sendiri mulau dari SDM organisasi itu sendiri sampai orang objek dari organisasi, kemudian objek organisasi jika saya kaitkan dengan pekerjaa sosial didalam tulisan ini berarti seorang klien yang menjadi tujuan rehabilitasi dari organisasi itu sendiri. Disini penulis merumuskan satu teori yang bertujuan untuk merekonstruksi suatu problema yang terjadi pada organisasi. Teori organisasi dari dari Stephen R. Robins merupakan bentuk teori organisasi yang relevan dengan permasalahan yang diangkat penulis di dalam tulisan ini, dimana pendekatan-pendekatan yang relevan dan bersifat resistensi dalam menghadapi permasalahan di dalam organisasi yakni cukup menjamin seperti goal attainment approach yang berarti menjawab tentang bagaimana keefektifan suatu organisasi harus berdasarkan tujuan yang ingin dicapai management 
by objectives yakni suatu manajemen yang menilai suatu organisasi berdasarkan atas kinerja anggota organisasi tersebut seberapa jauh mereka bekerja untuk mencapai tujuan, lebih khusus atas perintah yang ditetapkan oleh manajer atau kepemimpinan lembaga atau organisasi itu sendiri. Di mana MBO ini menggunakan cara, bahwasannya telah ditentukan masing-masing kinerja anggota suatu organisasi untuk bekerja dalam mencapai tujuan (Robins, 2010: 58-59).

Oleh karena itu, eksistensi organisasi berdiri semuanya memiliki tujuan yang harus dicapai, setidanya semua maslaah harus diidentifikasikan dan menstagnasikan suatu masalah. Pertama, menerima masukan dari semua anggota organisasi walaupun itu bukan senior dalam kelembagaa organisasi. Kedua, menyertakan tujuan yang dapat diperoleh dari tindakan-tindakan para anggota organisasi tersebut. Ketiga, bahwa semua organisasi memiliki tujuan yang harus dicapai dalam jangka pendek maupun jangka panjang. Keempat, menekankan organisasi pada tujuan yang harus dicapai dengan merealisasikan tujuan tersebut, dan mampu diverifikasi dan dapat diukur sebagai bentuk keefektifan suatu organisasi. Terakhir, melihat suatu tujuan organisasi sebagai bentuk yang fundamentalis dan dinamis. Karena dalam mengelola suatu organisasi sangat membutuhkan kesadaran dan intraktif dalam lingkungan organisai itu sendiri (Robins, 2010: 62-64).

\section{Hasil dan Pembahasan}

\section{Tantangan Pelayanan Sosial di Yayasan Sayap Ibu Cabang Yogyakarta}

Pelayanan sosial merupakan bentuk tindakan yang bekerja dengan membawa suatu tujuan atau orientasi terhadap keberhasilannyan dalam membantu permaslahan yang dihadapi oleh orang lain. Pelayanan menjadi bentuk tanggung jawab dan bekerja bersifat mengayomi maupun dengan jalan persuasif (Suharto, 2009: 158). Begitu juga soetarno melihat pelayanan merupakan bentuk kegiatan yang memiliki substansi di dalamnya memiliki serangkaian kegiatan yang jelas tujuannya.

Sehingga berbicara tentang pelayanan kinerja organisasi itu sendiri seperti bagaimana memberikan kinerja yang baik dan efektif dalam memberikan layanan terhadap klien. Akan tetapi pelayanan juga bisa terkendala dan terhambat dengan berbagai macam problematika. Misalnya manajemen pelayanan di Yayasan Sayap Ibu Cabang Yogyakarta dimana manajemen organisasi juga termasuk dalam bagian dari 
pelayanan terhadap klien-kliennya, akan tetapi beberapa kendala yang terkait dengan manajemennya yang berimbas terhadap ketidakefektifan dalam menjalankan pelayanannya. Pertama, terkait dengan pendanaan, karena dimana organisasi sosial yang bersifat swasta atau berdiri akan inisiasi masyarakat itu sendiri atau secara pribadi, tentu tidak memiliki subsidi dana yang begitu lancar dan efektif seperti organisasi pemerintahan. Sehingga disaat kurangnya pemasukan terhadap pendanaan pada yayasan, akan memicu kurangnya keefektifan terhadap proses layanan, mengingat semua kebutuhan bersumber dari dana pribadi. Jadi, hal itu sangat menjadi tantangan dalam proses layanan karena mengacu kepada seluruh elemen atau bagian yayasan baik dari kebutuhan, sumber daya mansusianya bahkan sampia melihat kemirisan pada klien yang di rehabilitasi di Yayasan Sayap Ibu Cabang Yogyakarta. Kedua, kurangnya komitmen terhadap sumber daya manusia didalam panti, dimana ketika mengalami fenomena pegawai yang resign atau berhenti bekerja, dan hal itu juga memicu kurangnya pegawai didalam panti itu sendiri, dan menyebabkan kurangnya efektifitas terhadap proses pelayanan sosial yang terjadi di Yayasan Sayap Cabang Yogyakarta.

\section{Dampak Pelayanan Sosial di Yayasan Sayap Ibu Cabang Yogyakarta}

Berbicara tentang pekerjaan sosial tidak akan pernah lepas dengan bagaimana memberikan bantuan atau pelayanan terhadap orang lain. Bahkan secara manusiawi tujuan dari pelayanan dalam lembaga sosial ini meningkatkan Hak asasi manusia itu sendiri, dimana setiap manusia memiliki hak untuk hidup sejahtera, karena Hak asasi dalam diri manusia merupakan bentuk apresiasi yang harus dihormati ( Putrawan, 2016, 183). Di mana profesi ini, memang diarahkan untuk memperbaiki kondisi-kondisi manusia, sosial serta mengurangi kesulitan dan memecahkan permasalahan yang dihadapi (Damanik, 2008, 1). Sehingga profesi ini juga bersifat melembaga dan terorganisir, dengan eksistensi kelembagaan itu, menjadi ruang bagi merehabilitasi klien-kliennya.

Kemudian dalam setiap tindakan dalam memberikan pelayanan, tentu pekerjaan sosial juga mengalami berbagia macam kendala, jika penulis singgungkan disini mengenai pekerjaan sosial di Yayasan Sayap Ibu Cabang Yogyakarta, tentang bagaimana kendala dan tantangan atas manajmen pelayanannya, tentu hal itu juga bisa merampungkan beberapa dampak yang membeuat tidak efektif maupun efisiennya 
pelayanan. Di sini penulis memaparkan dampak terhadap tantangan manajemen yang menghambat efektifitasnya pelayanan di Yayasan Sayap Ibu Cabang Yogyakarta yakni. Ketika berbicara tentang manajamen, tentu berbicara tentang bagaimana pengelolaan secara administratif didalam suatu lembaga, bahwasanya tantangan manajemen itu mampu merubah keefektifan jalannya pelayanan di dalam lingkup lembaga, misalnya kurangnya modal atau pendanaan yang menjadi faktor utama tidak lancarnya pelayanan. Dimana kita ketahui, bahwasanya pendanaan atau modal memang sangat penting didalam setiap agenda, apalagi soal menyoal tentang pelayanan pekerjaan sosial yang berada dalam organisasi non profit atau non pemerintahan seperti organisasi sosial Yayasan Sayap Ibu Cabang Yogyakarta.

Dari uraian problem tersebut, tentau memicu dampak yang sangat signifikan. Karena kurangnya pendanaan di dalam suatu organisasi sosial non-pemerintah seperti yayasan sayap ibu juga menyebabkan tidak efektifnya pelayanan, kadang secara aset pendanaan juga sifatnya tentatif atau tidak tentu, bahkan sumbangan lahir dari berbagai pihak dengan jumlah yang tidak begitu banyak, dan ketika menerima problem seperti itu, menjadi problem yang signifikan karena menghambat keefektifan pelayanan didalam suatu lembaga seperti kurangnya biaya atau financial untuk memenuhi kebutuhan di dalam lembaga seperi kebuthan anak-anak atau klien didalam lembaga yayasan sayap ibu cabang Yogyakarta, bahkan kebutuhan dalam memberikan gaji bagi karyawan di dalam panti. Kadang yang paling ironis, ketika lembaga menerima permasalahan terkait dengan resign atau pemundura diri atas karyawannya, itu sangat menyababkan kurangnya efektifnya pelayanan. Dimana kekurangan pegawai yang harus siap bekerja secara sukarelawan dalam merehabilitasi anak terlantar.

Akan tetapi, ketika terjadi permasalahan tersebut, menjadikan berbagai macam kendala yang terjadi seperti kurangnya pegawai bahkan berdampak pada ketidak efektifan pelayanan didalam lembaga. Karena tidak bisa dipungkiri, hak-hak klien yang direhabilitasi didalam lembaga yayasan sayap ibu cabang Yogyakarta juga merupakan bagian dari ciptaan tuhan yang sangat perlu memiliki hak untuk hidup sejahtera. Misalnya kliennya yang bersifat anak terlantar balita, dalam hak itu berhak memiliki orang tua, karena setiudaknya lazimnya anak berusia 0-5 tahun itu sangat membutuhkan belaian orang tua. Anak sejak masih usia 0-2 tahun itu menjadi usia yang masih menerima air susu orang tuanya (Putrawan, 2016: 186), Sehingga setiap pelayanan yang 
diresapi didalam lembaga sangat membutuhkan keefektifan dan kelancaran yang maksimal, dimana melaihat eksisten di lembaga memang sebagai organisasi provit atau organisasi yang berdiri sendiri, tentu itu sangat membutuhkan berbagai macam donasi yang kuat dan pelayanan yang maksimal dalam merehabilitasi klien-kliennya.

Melihat eksistensi klien anak telantar itu yang tak terlepas dari bagaimana melihat perbandingan dengan mereka yang hidup dengan kasih sayang orang tua dan keluarga yang harmoni, hal itu juga berdampak bagi perkembangan mereka yang jauh berbeda dengan anak pada umumnya. Karena eksistensi keluarga memang sebagai pola pendidikan, terutama dari kasih sayang orang tua, karena tidak bisa dipungkiri bahwasannya keluarga memang menjadi pengalaman pertama seorang anak untuk mengenal dunia.

\section{Resistensi Pekerja dalam Menghadapi Problem Manajemen}

Entitas organisasi sosial, tidak akan lepas dari dorongan dan eksistensi agenagen yang berada didalam lembaga atau organisasi itu sendiri. Kemudian ketika berbicara tentang pekerjaan sosial, juga tidak lepas dari beberapa tujuan berdirinya profesi ini yakni meningkatkan kemmapuan orang dalam menghadapi masalahnya atau memotivasi klien-kliennya, menghubungan individu dengan sumber-sumber, meningkatkan kinerja kelembagaan, menciptakan kondisi kondusif dan mencapai tujuan dalam pelayanan (Suharto, 2009: 5).

Dari beberapa tujuan pekerjaan sosial itu, bisa bisa dirampungkan atau disimpulkan bahwa pekerjaan sosial bertujuan untuk memberikan pelayanan sebaik mungkin pada suatu individu meningkatkan keberfungsian sosial seseorang. Keberfungsian berarti mampu bertindak dan memerankan diri dalam menjalankan sosialnya. Kemudian disini penulis singgungkan dengan garapan pekerjaan sosial yang begitu variatif misalnya pelayanan anak dan keluarga, kesehatan dan rehabilitasi, pengembangan masyarakat, dan jaminan sosial (Suharto, 2009: 6).

Oleh karena itu, jika kita menilik tentang garapan dan tujuan pekerjaan sosial, tentu profesi ini menjadi profesi yang harus dilandasi dengan jiwa sosial yag tinggi, dimana slogan pekerjaan sosial dalam melhat kliennya tetap menjadi manusia yang unik dan tidak berbeda dari dirinya sendiri. Namun ketika ketika para praktisioner pekerjaan sosial menhdapi permasalahan baik secara personal maupun kelembagaan, tentu hal itu 
akan menyebabkan berbagai macam kendala dan tantangan yang harus diterima sebagai sebuah profesi.

Sehingga ketika menerima tantangan tersebut, agar terus menjamin pelayanan yang baik dan maksimal, dimana pekerja sosial yang terlahir sebagai para stakeholders untuk perubahan sosial. Di yayasan sayap ibu cabang yopgyakarta merupakan salah satu organisasi sosial non-pemerintahan yang memiliki fokus rehabilitasi pada bidang anak terlantar. Akan tetapi, tidak semua lembga atau agenda yang tidak disentuh dengan tantangan, begitu pula dengan tantagan pelayanan sampai ke tantangan manajemen kelembagaan.

Namun, dalam menghadapi tantangan di lembaga yayasan sayap ibu cabang yogyakarta juga memiliki resistensi agar terus melahirkan keefektifan dalam memberikan pelayana dan rehabilitasi terhadap klien-kliennya yakni. Pertama, menerima semua masukan dari semua elemen atau kepegawaian didalam lembaga mengenai bagaimana caranya untuk menstagnasikan problem yang dihadapi, begitu juga dengan problem manajemen didalam lembaga. Karena dengan mendengear semua aspirasi dan masukan dari semua anggota kepegaiwan, dari staf, pekerja sosia, perawat, dan semua yang terimplikasi sebagia SDM lembaga, paling tidak itu bisa memberikan arahan yang cukup baik dan kondusif untuk memecahkan permasalahan.

Kedua, menentukan tujuan yang jelas pada organisasi tersebut, artinya ketika menerima permasalahan tentang manajemen, para peggawai kelembagaan menyertakan tujua yang jelas pada organisasi misalnya di Yayasan Sayap Ibu bertujuan dalam memberikan pelayanan yang efektif dan kondusif walaupun bersifat non-profit. Akan tetapi tujuan tersebut harus menjadi acuan dalam setiap evaluasi, dalam mengahapi tantangan manajemen kurangnya pendanaan, kurangnya pegawai dan lemahnya pelayanan. Para pegawai terutama menyertakan tujuan dan mengklarifikasi permasalahan tersebut dan di diskusikan dengan semua pegawai lembaga di Yayasan Sayap Ibu Cabang Yogyakarta.

Ketiga, kepala panti bersikap keras dalam bertindak bagaimana caranya untuk mendapatkan pendanaan agar terus menjamin keefektifan dalam memberikan pelayanan terhadap klien-kleinnya yakni dengan cara kadang menerima pendanaan dari orangorang yang berjiwa sosial, kadang itu di klaim sebagai manjurnya doa-doa para pegawai atas bagaimana merealisasikan pengasuhan yang baik kepada anak-anak terlantar, 106 
bahkan kadang tindakan dinamis dari kepala panti atau dari beberapa pegawai yang mengajukan proposal untuk menutupi kekurangan terhadap financial lembaga, dan melakukan korelasi dengan beberap perusahan besar ataupun dengan dinas sosial.

\section{Kesimpulan}

Yayasan Sayap Ibu Cabang Yogyakarta merupakan organisasi sosial non-profit yang mengalami ketidak efektififan dan terkendalanya rangkaian pelayanan dalam merehabilitasi klien-kliennya. Seperti lemahnya pendanaan yang menyebabkan lemahnya pelayanan yang dilakukan. Keberadaan financial atau ketersediaan pendanaan yang mencukupi memang sangatlah penting dalam membantu melancarkan proses pelayanan yang efektif dan efisien. Beberapa tindakan resistensi yang dilakukan untuk menstagnasikan permasalahan dalam manajamen dan menyebabkan lemahnya keefektifan terhadap pelayanan sosial yakni (a) menerima semua masukan dari semua elemen atau kepegawaian didalam lembaga mengenai bagaimana caranya untuk menstagnasikan problem yang dihadapi, (b) menentukan tujuan yang jelas pada suatu organisasi ketika menerima permasalahan tentang manajemen, para pegawai kelembagaan menyertakan tujuan yang jelas. Tujuan tersebut harus menjadi acuan dalam setiap evaluasi, dalam mengahapi tantangan manajemen kurangnya pendanaan, kurangnya pegawai dan lemahnya pelayanan, (c) kepala panti bersikap keras dalam bertindak untuk mendapatkan dana agar menjamin pelayanan yang efektif terhadap klien. 


\section{Referensi}

Asyhabudin. (2015). "Membangun Keluarga Sakinah Perspektif Pekerjaan Sosial". Jurnal Komunika, Vol 9, No 2 Juli-Desember.

Damanik, J. (2008). Pekerjaan Sosial. Direktorat Pembinaan Sekolah Menengah Kejuruan.

Dedi Putrawan, A. (2016). Membumikan Deklarasi Kairo di Indonesia: Perlindungan Terhadap Hak Anak dan Keluarga. Jurnal Tasamuh, Vol 13. No 2 Juni.

Farikhah, S. (2011). Manajemen Lembaga Pendidikan. Yogyakarta: Aswaja Pressindo.

Heru Sukonco, D. (2006). Profesi Pekerjaan Sosial dan Proses Pertolongannya. Sekolah Tinggi Kesejahteraan Sosial.

Huda, M. (2009). Pekerjaan Sosial dan Kesejahtraan Sosial. Yogyakarta: Pustaka Pelajar.

Husna, N. (2009). Pelayanan Kesejahteraan Sosial bagi Lansia.

Kartika Dewi, N. (2016). "Peluang dan Tantangan Menjadi Konselor di Era Masyarakat Asean (MEA)". Proceedings International Seminar FoE (Faculty of Education), Vol. 1 .

Mohamad, Y. (2010). "Pemberdayaan Masyarakat Miskin melalui Program Nasional Pemberdayaan Masyarakat". Tesis, UIN Sunan Kalijaga Yogyakarta.

Najib, A. (2018). Pekerjaan Sosial Perspektif Islam dan Filantropi. Yogyakarta: Samudra Biru.

Nazarudin, P. (2001). Isu-Isu Tematik Pembangunan Sosial: Konsepsi dan Strategi. Badan Pelatihan dan Pengembangan Sosial, Kementerian Sosial RI.

Robins, S. R. (2010). Teori Organisasi Struktur, Desain, dan Aplikasi. Perpustakaan Nasional, Katalog dalam Terbitan (KDT).

Roy Monteiro, B. (2019). "Analisis Efektiftas Pelayanan Pembuatan Surat Tanda Nomor Kendaraan di Kantor Samsat Kota Makasar." Jurnal Dinamika Sosial, Vol 3, No 2, Agustus.

Soetarso. (1997). Kesejahteraan Sosial, Pelayanan Sosial dan Kebijakan Sosial. Sekolah Tinggi Kesejahteraan Sosial.

Suasa. (2009). Pelayanan Langsung dan Pelayanan Tidak Langsung Dalam Pekerjaan Sosial. Jurnal Academica Fisip UNTAD, Volume I. 
Suharto, E. (2009a). Membangun Masyarakat, Memberdayakan Rakyat. Bandung: Refika Aditama.

Suharto, E. (2009b). Pekerjaan Sosial di Dunia Industri. Bandung: Alfabeta.

Suharto, E. (2013). Kemiskinan dan Perlindungan Sosial di Indonesia. Bandung: Alfabeta.

ST. Raharjo, (2002). "Manajemen Relawan Pada Organisasi Pelayanan Sosial". Jurnal Sosiohumaniora, Vol. 4, No. 3.

Teguh Paripurno, E. (t.t.). Modul Manajemen Bencana Seputar Beberapa Bencana Di Indonesia. http://www.bapeda-jabar.go.id di akses tanggal 15 Januari 2020.

Usman, H. (2013). Manajemen Teori Praktik dan Riset Pendidikan. Lampung: Bumi Aksara.

Yulian, V. (2006). Pelayanan Kesejahteraan Sosial Bagi Lanjut Usia. 